\title{
MACROAGGREGATION OF A PALEUDALF AFFECTED BY CAVITATION INTENSITY AND MANAGEMENT SYSTEMS WITH COVER PLANTS
}

\author{
MACROAGREGAÇÃO DE UM ARGISSOLO AFETADA PELA INTENSIDADE DE \\ CAVITAÇÃO E SISTEMAS DE MANEJO COM PLANTAS DE COBERTURA \&
}
MACROAGREGACIÓN DE UN PALEUDALF AFECTADA POR LA INTENSIDAD DE CAVITACIÓN Y SISTEMAS DE MANEJO CON PLANTAS DE COBERTURA \&

Recebido em: 03/03/2021 - Aprovado em: 22/09/2021 - Publicado em: 05/10/2021

http://dx.doi.org/10.18011/bioeng2021v15n2p283-302
Érika Andressa da Silva ${ }^{1}$ (andressaerikasilva@gmail.com)
Micael Stolben Mallmann² (micaelstolben@gmail.com)
Monike Andrade Pereira² (monikeandrade.pereira@hotmail.com)
Sarah Severo Pons² (sarahsevero@hotmail.com)
Felipe Dalla -Zen Bertol² (fe_bertol@hotmail.com)
José Miguel Reichert² (reichert@ufsm.br)
Dalvan José Reinert² (dalvan@ufsm.br)

1 Universidade do Estado de Minas Gerais (UEMG). Passos, Minas Gerais, Brasil.

2 Universidade Federal de Santa Maria (UFSM). Santa Maria, Rio Grande do Sul, Brasil.

\begin{abstract}
Although they result in the same applied energy, certain combinations of time and power might correspond to different intensities of cavitation. Consequently, several responses in aggregation indexes can be obtained with different configurations of ultrasound techniques. Thus, this work aimed to evaluate the effects of cavitation intensity in the distribution of aggregates of a Paleudalf under management systems with cover plants and to compare aggregate stability determination methods (ultrasound versus wet sieving -WS). Aggregate samples of the treatments bare soil, black oat + forage turnips and black oat + hairy vetch were exposed to ultrasonic irradiation in different combinations of potency and time: $74.5 \mathrm{~W} / 4 \mathrm{~s} ; 49.7 \mathrm{~W} / 6 \mathrm{~s} ; 74.5$ $\mathrm{W} / 10 \mathrm{~s}$ and $49.7 \mathrm{~W} / 15 \mathrm{~s}$. The geometric mean diameter (GMD) and mass-weighted mean diameter (WMD) were calculated. The amplitude of vibration exerted greater influence on soil breakdown than the total energy applied. In the WS method observed greater GMD and WMD.
\end{abstract}

Keywords: Amplitude of vibration. Ultrasound. Wet sieving.

Artigo publicado sob a licença Creative Commons - Atribuição 4.0 Internacional (CC BY 4.0). 


\section{INTRODUCTION}

Unlike wet sieving, ultrasonic-based techniques allow the prediction of the energy required to break the aggregate and, for this reason, have been more commonly used to measure the stability of aggregates (RIBEIRO et al., 2017; SILVA et al., 2016; SILVA et al., 2021).

Disaggregation caused by the exposure of the aggregates to the ultrasonic energy can be explained by modeling. The first models proposed for the evaluation of the stability of aggregates by ultrasonification expressed the soil disaggregation based on the increase of dispersed clays as a function of sonification time (NORTH, 1976). This methodology represented well the dispersion of temperate soils, because in these soils, after sonification, the clay remained dispersed for several hours, facilitating its quantification.

The modeling proposal described by North (1976) cannot be applied to soils with a high degree of flocculation, such as the Brazilian Oxisols. In These soils, after being subjected to sonification, the clay does not remain dispersed long enough to quantify it. Thus, for soils of Brazil, Sá et al. (1999) proposed the dispersion index (DI), which relates the content of dispersed silt/clay particles and the released aggregates to a specific energy level (SILVA et al., 2019).

The dispersion index, regardless of the type of soil, can be compared within each specific energy level applied or even plotted in dispersion curves. Generally, these curves exhibit hyperbolic behavior with two well-defined regions. The first, ascending, represents the soil disaggregation as a function of the specific applied energy. The second is defined by the dispersion plateau, represented by the region in which a constant value is reached (SÁ et al., 1999).

In several studies, this index was more sensitive to evaluate the influence of soil management on the stability of aggregates, reaching a higher efficiency than traditional soil aggregation measurement methods, such as indexes obtained by wet sieving (SÁ et al., 2000; RIBEIRO et al., 2013; RIBEIRO et al., 2009).

However, certain combinations of time and power might correspond to different intensities of cavitation. Consequently, different responses in aggregation indexes can be obtained with ultrasound techniques (RIBEIRO et al., 2017).

The cavitation phenomenon is characterized by formation, growing, and implosion of air bubbles into the suspension (PILLI et al., 2011), which are responsible to disperse the 
soil (RIBEIRO et al., 2017). The power displayed on the ultrasound may differ from the actual power output depending on equipment, insertion depth and geometry of the ultrasonic probe (RIBEIRO et al., 2017). In certain vibration amplitude the absorbed ultrasonic power increases with increasing insertion depth (SILVA et al., 2016). With increasing vibration amplitudes, cavitation and subsequent stressing of soil particles increases and causes more frequent fracture of soil particles (MAYER et al., 2002). Ultrasonic dispersion experiments at different vibration amplitudes and low absorbed energies may serve therefore to separate macroaggregates of different stability (SILVA et al., 2016, SILVA et al., 2019).

Sonication has been a useful tool to evaluate the effect of cover crops on the macroaggregation (SILVA et al., 2016; SILVA et al., 2019; SILVA et al., 2021). Silva et al. (2019) demonstrated that cover crops influenced the critical energy (CE) levels required for dispersion of aggregates of the Hapludalf. Under the conditions of that study the conservation management with black oats and vetch increased the soil structural stability, which was expressed by the increment of the CE, and lower normalized dispersion index (NDI) and b/a index.

In other study carried by Silva et al.(2021), the soil use with spontaneous vegetation negatively affected the aggregates stability, while cover crops: black oat + forage turnips, black oat + hairy vetch, pensacola grass, forage peanut presented tendency to improve soil aggregation long-term, requiring greater energy for aggregates dispersion than bare soil. Soil management systems with cover crops increase the amount of phytomass deposited on the soil surface. In addition to protecting the soil from rainfall impacts with reduction of erosion processes (SILVA et al., 2019), this plant material increases the microbial activity, the accumulation of nutrients and organic matter in the superficial layers and consequently favors the increase of soil aggregate stability after its decomposition (LOSS et al., 2015).

Thus, this work was carried out to evaluate the effects of cavitation intensity in the distribution of aggregates of a Paleudalf under management systems with cover plants and to compare aggregate stability determination methods (ultrasound versus wet sieving).

\section{MATERIAL AND METHODS}

\subsection{DESCRIPTION OF THE EXPERIMENTAL AREA}

The study was carried out in the experimental area of the Soil Department of the Federal University of Santa Maria (UFSM), Santa Maria, Rio Grande do Sul, Brazil. The 
climate of the region is Cfa according to the Köppen classification (ALVARES et al., 2013), which corresponds to the humid subtropical climate without drought periods. The average temperature of the hottest month reached $22^{\circ} \mathrm{C}$, and the temperature of the coldest month ranges between $-3^{\circ} \mathrm{C}$ and $18^{\circ} \mathrm{C}$. The soil of the study area is classified as Paleudalf (Classification according to Soil Taxonomy: USDA, 2010).

In April 2010, an experiment was conducted to evaluate the effects of injecting swine wastewater into the soil. The area was cultivated with oat-maize succession until March 2015. From that date the area remained fallow until February 2016. The experiment consists of three treatments and four blocks, totaling 12 experimental units of $3 \times 14.55 \mathrm{~m}\left(43.5 \mathrm{~m}^{2}\right)$, distributed in a randomized block design. The plots are delimited by $30-\mathrm{cm}$ galvanized sheets nailed up to $10 \mathrm{~cm}$ in the soil and the average slope is around $5 \%$. The longest length of the experimental units lies in the direction of the slope.

The treatments consisted in the implantation of different cover plants in monoculture or in rotation systems. The cover plants used were: black oat (Avena strigosa Schreb) + forage turnip (Raphanus sativus L.) + kidney beans (OT); black oat (Avena strigosa Schreb) + hairy vetch (Vicia villosa Roth) + kidney beans (OV); and a control plot, bare soil (BS).

The oat + turnip and oat + vetch crops were sown in the fall/winter period. The percentages of $30 \%$ and $70 \%$ of the recommended total per hectare were used for oat and turnip cultivations, which corresponded to 100 and $15 \mathrm{~kg} \mathrm{ha}^{-1}$, respectively. The oat and vetch crops were sown at $45 \%$ and $55 \%$ of the recommended total per hectare, corresponding to 100 and $80 \mathrm{~kg} \mathrm{ha}^{-1}$, respectively. The bare soil treatment was maintained without vegetation with the use of periodically chemical weeding ( $\mathrm{L} \mathrm{ha}^{-1}$ of glyphosate). This method was chosen to avoid soil disturbance.

For the evaluation of the stability of the aggregates by the different methods (sonification and wet sieving), soil monoliths with preserved structure were collected in the 0.0-0.05 m layer for all treatments. The soil samples were air dried and the aggregates were manually handled and gently passed through a set of sieves to obtain aggregates with size ranging from 4.76 to $8 \mathrm{~mm}$.

Following the methodology of Tedesco et al. (1995), chemical analyzes were performed to characterize all treatments in the experimental area (Table 1). 
Table 1- Chemical characterization of the soil under management with different cover plants.

\begin{tabular}{rcccccccc}
\hline Treatments & $\mathbf{p H}$ & $\mathbf{P}$ & $\mathbf{K}^{+}$ & $\mathbf{C a}^{2+}$ & $\mathbf{M g}^{2+}$ & $\mathbf{A l}^{3+}$ & $\mathbf{H + A l}$ & $\begin{array}{c}\text { SOM } \\
\text { OV }\end{array}$ \\
& 4.3 & $\ldots 0$ & 0.36 & 2.30 & 0.85 & 0.7 & 6.0 & 2.1 \\
OT & 4.3 & 46 & 0.34 & 1.92 & 0.64 & 0.75 & 6.4 & 2.3 \\
BS & 4.2 & 77 & 0.20 & 1.52 & 0.53 & 1.1 & 6.4 & 2.1
\end{tabular}

OV: oat + vetch, OT: oat + turnip, BS: bare soil; $\mathrm{pH}$ in water (ratio soil:water 1:2.5), SOM: Soil organic matter, $\mathrm{P}$ : Phosphorus, K: potassium, Ca: calcium, Mg: magnesium, Al: aluminium, $\mathrm{H}+\mathrm{Al}$ : hydrogen and aluminum.

Source: Authors, 2021.

\subsection{EVALUATION OF THE SIZE DISTRIBUTION OF STABLE AGGREGATES IN WATER}

The standard method of wet sieving was used to evaluate the distribution of the size of stable aggregates in water. The sieving of the aggregates in water was performed on a Yoder vertical oscillator for ten minutes (30 oscillations per minute). Samples of $25 \mathrm{~g}$ of aggregates with diameters between 8 and $4.76 \mathrm{~mm}$ were screened using sieves with mesh diameter of $4.76 ; 2.0 ; 1.0$ and $0.25 \mathrm{~mm}$, which allowed the separation of the aggregates into five classes ( $8.00-4.76,4.76-2.00,2.00-1.00,1.00-0.25$ and, $<0.25 \mathrm{~mm})$. The soil remaining in each sieve was weighed after oven drying $\left(105^{\circ} \mathrm{C}\right)$ and dispersed with $6 \%$ $\mathrm{NaOH}$ to discard inert materials such as sand and other impurities. In order to quantify the structural stability of the soil, the geometric mean diameter (GMD) and the mass-weighted mean diameter (WMD) were determined according to Kemper and Chepil (1965).

\subsection{AGGREGATION INDEXES MEASURED BY ULTRASONIC ENERGY AT DIFFERENT CAVITATION INTENSITIES}

A total of $25 \mathrm{~g}$ of aggregates (oven-dried based) were placed in a $250-\mathrm{mL}$ beaker with a slope of $45^{\circ}$. In this condition and with the aid of a burette, the aggregates were moistened with a drip rate directed to the wall of the beaker with 45 drops per minute. After all the aggregates were immersed in the water, dripping was ceased and the volume was completed to $200 \mathrm{~mL}$. Sonification was carried out in a Vibracell Sonics, equipped with a titanium probe (diameter 19.1 -mm diameter) immersed up to $2 \mathrm{~cm}$ in the soil suspension.

The soil-aggregate suspensions were irradiated by ultrasonic waves at different power levels after calibration by calorimetric techniques. Four different amplitudes were employed: $25,30,35$, and $40 \mu \mathrm{m}$. In each sonication condition the displayed output power 
was checked based on calorimetric techniques (Figure 1) (SILVA et al., 2021), according to the following equation 1.

$$
\mathrm{P}=\left[\left(\left(\mathrm{m}_{\mathrm{a}} \cdot \mathrm{c}_{\mathrm{a}}\right)+\mathrm{c}_{\mathrm{g}}\right) \frac{\Delta \mathrm{T}}{\Delta \mathrm{t}}\right]
$$

in which $\mathrm{P}$ is the power determined by calorimetry (W); ma is the mass of water (200 $\mathrm{g})$; $\mathrm{ca}$ is the water specific heat capacity $\left[4,186 \mathrm{~J} \mathrm{~g}^{\circ} \mathrm{C}^{-1}\right]$; $\mathrm{cg}$ is the beaker specific heat capacity $\left(\mathrm{J}^{\circ} \mathrm{C}^{-1}\right), \Delta \mathrm{T}$ is the increase in the temperature of the water during the period of time $\Delta \mathrm{t}$.

Figure 1 - Calorimetrically determined power in function of the amplitude selectioneted in display equipament.

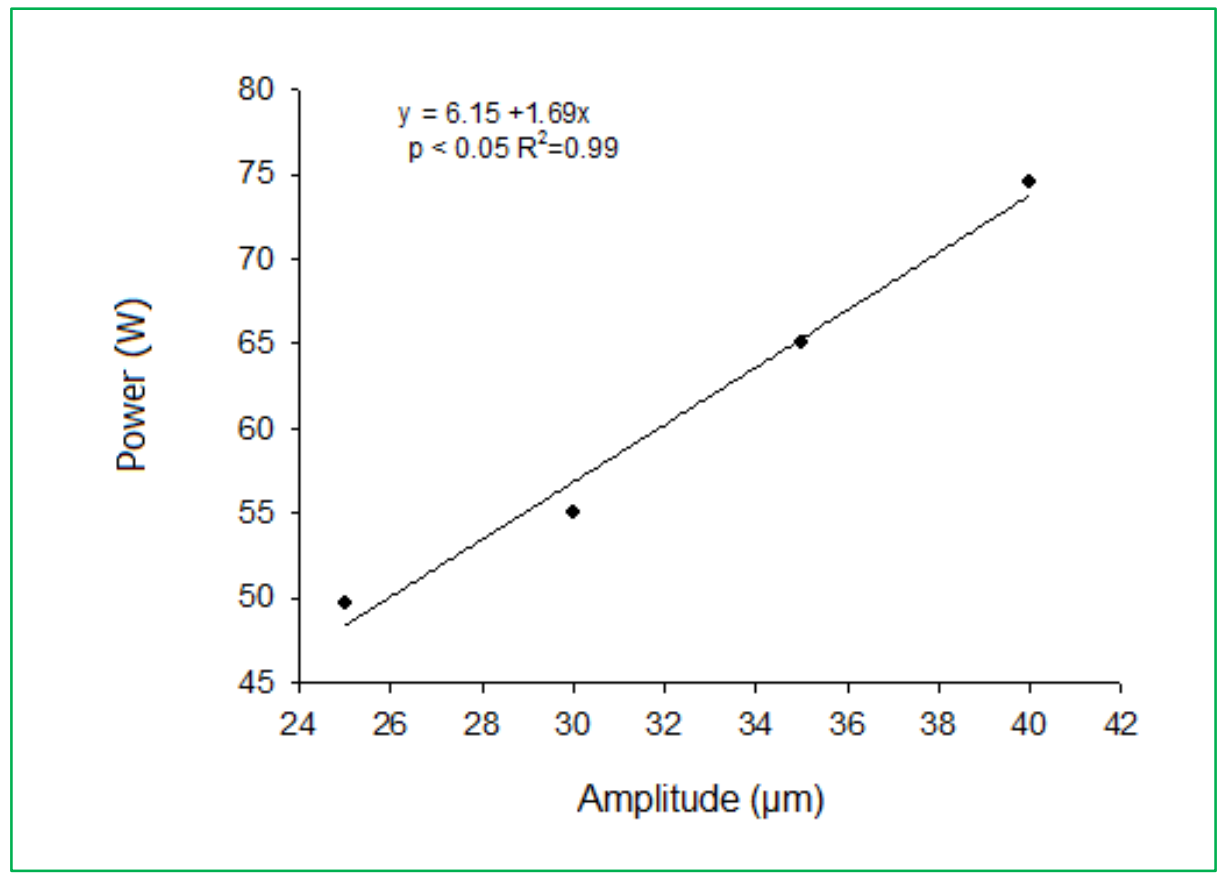

Source: Authors, 2021.

The beaker specific heat capacity $(\mathrm{cg})$ was calculated by equation 2 :

$\mathrm{c}_{\mathrm{g}}=\mathrm{c}_{\mathrm{v}} \cdot \mathrm{m}_{\mathrm{b}}$

Where $\mathrm{cg}$ is the beaker specific heat capacity $\left(\mathrm{J}^{\circ} \mathrm{C}^{-1}\right)$; $\mathrm{cV}$ is the glass specific heat capacity $\left(840 \mathrm{~J}^{\circ} \mathrm{C}^{-1} \mathrm{~kg}^{-1}\right)$; and $\mathrm{mb}$ is the mass of the beaker $(\mathrm{kg})$.

The power and time combinations were the following: i) $74.5 \mathrm{~W}$ for $4 \mathrm{~s}$ (method U1), ii) $49.7 \mathrm{~W}$ for $6 \mathrm{~s}$ (method U2), iii) $74.5 \mathrm{~W}$ for $10 \mathrm{~s}$ (method U3), and iv) $49.7 \mathrm{~W}$ for $15 \mathrm{~s}$ (method U4). For U1 and U2, the total energy applied was $1.49 \mathrm{~J} \mathrm{~mL}^{-1}$ or $11.92 \mathrm{~J} \mathrm{~g}^{-1}$ and for U3 and U4, the total energy applied was $3.725 \mathrm{~J} \mathrm{~mL}^{-1}$ or $29.8 \mathrm{~J} \mathrm{~g}^{-1}$. 
The temperature in function of the sonification time was monitored with a thermometer. The decay of the power in the display of the ultrasound was monitored as a function of the increase in temperature. Subsequently, these values were corrected by determining the actual operating power by calorimetric techniques. The amplitudes of $25 \mu \mathrm{m}$ and $40 \mu \mathrm{m}$ correspond to the powers $49.7 \mathrm{~W}$ e $74.5 \mathrm{~W}$, respectively. The same ultrasonic probe was used in all experiments.

After each sonification, the soil aggregate suspension was carefully passed through the same set of sieves (8.00 - 4.76, $4.76-2.00,2.00-1.00,1.00-0.25$, and $<0.25 \mathrm{~mm}$ ) used in the standard method of wet sieving. The soil mass retained in each sieve was oven dried at $105^{\circ} \mathrm{C}$ for 48 hours. Samples were dispersed in $6 \% \mathrm{NaOH}$ in order to discard inert materials such as sand and other impurities contained in each class. Finally, the mass of aggregates retained in each size fraction and WMD/GMD aggregation indexes as in Kemper and Chepil (1965) were calculated according to the following formulas 3 and 4.

$$
\text { WMD: ¿xiyi }
$$

where yi is the proportion of each size class with respect to the total sample and $x i$ the mean diameter of the size class $(\mathrm{mm})$.

Geometric mean diameter was calculated as follows:

GMD: $\exp \{\Sigma$ wi In xi/ $\Sigma$ wi $\}$

where wi is the weight of the aggregates of each size class (g) and In xi the natural logarithm of the mean diameter of size classes.

The experimental design consisted of three treatments, four methods of sonification (combinations of time and power) and three replications, totaling 36 samples. The data were submitted to analysis of variance and, when pertinent, the means were compared by the Tukey test, with $5 \%$ probability using the $R$ software ( $R$ Core Team 2018 ). The results of this study were also compared with the results obtained by the wet sieving (WS) method. 


\section{RESULTS}

\subsection{CAVITATION INTENSITY: INFLUENCE ON THE DISTRIBUTION OF AGGREGATES IN SIZE CLASSES}

There was an increase in the temperature of the suspension (water: aggregates) during the sonification period with the different powers (74.5 and $49.7 \mathrm{~W}$ ) (Figure 2). Suspension temperature rose faster at high sonification power. At the power of $74.5 \mathrm{~W}$, the temperature raised from $17^{\circ} \mathrm{C}$ to $23^{\circ} \mathrm{C}$ in 39 seconds, while at the power of $49.7 \mathrm{~W}$ it took 150 seconds.

Figure 2- Increase in suspension temperature (water: aggregates) as a function of power and sonification time.

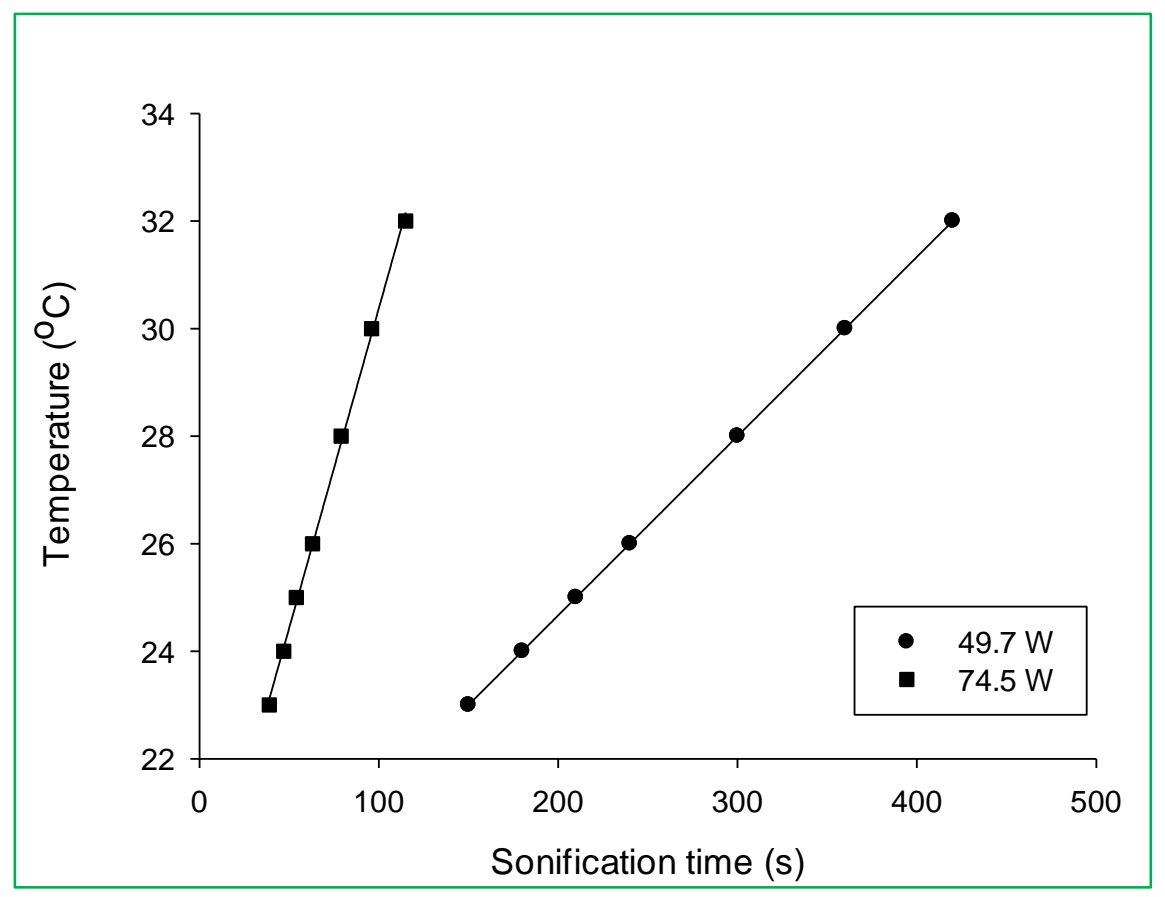

Source: Authors, 2021.

The calorimetrically determined power increased linearly with amplitude (Figure 1). The increase in temperature causes a reduction in the power emitted by the ultrasound (Figura 3b). For this reason the amplitude of vibration (or cavitation intensity) decreased with increasing temperature (Figure 3a). 
Figure 3-a) Decline of the Amplitude (cavitation intensity) in function of the temperature of the suspension (water: aggregates) and b) Decline of Power in function of the temperature of the suspension (water: aggregates).

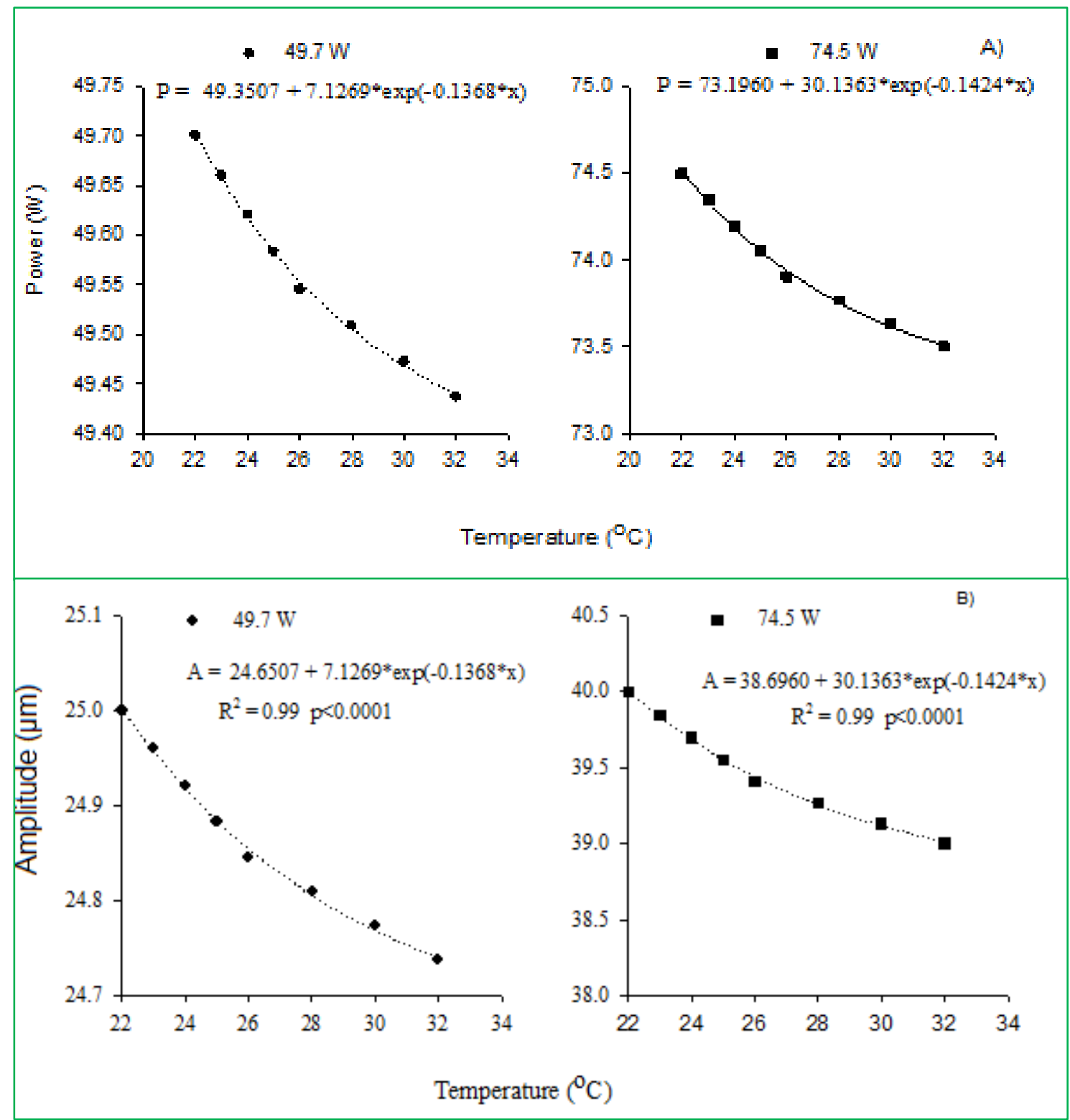

Source: Authors, 2021.

Although the time and power combinations used in the sonification test U1 (P: 74.5 $\mathrm{W}$ and T: $4 \mathrm{~s}$ ) and $\mathrm{U} 2$ (P: $49.7 \mathrm{~W}$ and $\mathrm{T}: 6 \mathrm{~s}$ ) represented the application of the same total energy $\left(1.49 \mathrm{~J} \mathrm{~mL}^{-1}\right.$ or $\left.11.92 \mathrm{~J} \mathrm{~g}^{-1}\right)$, different responses in the distribution of aggregates in size classes were observed in the tested treatments BS, OV and OT (Figure 4). For the bare soil and for the vegetal coverings (OV, OT), the aggregate mass retained in the size class 8.0-4.76 $\mathrm{mm}$ was higher when using the $\mathrm{U} 2$ sonification method. 
Figure 4 - Mass of aggregates (dag kg-1) in the different size classes obtained after exposure to the $\mathrm{U} 1$ and U2 sonification methods corresponding to the total applied energy level of $1.49 \mathrm{~J} \mathrm{~mL}^{-1}$ or $11.92 \mathrm{~J} \mathrm{~g}^{-1}$.

OV: oat + vetch, OT: oat + turnip, BS: bare soil.

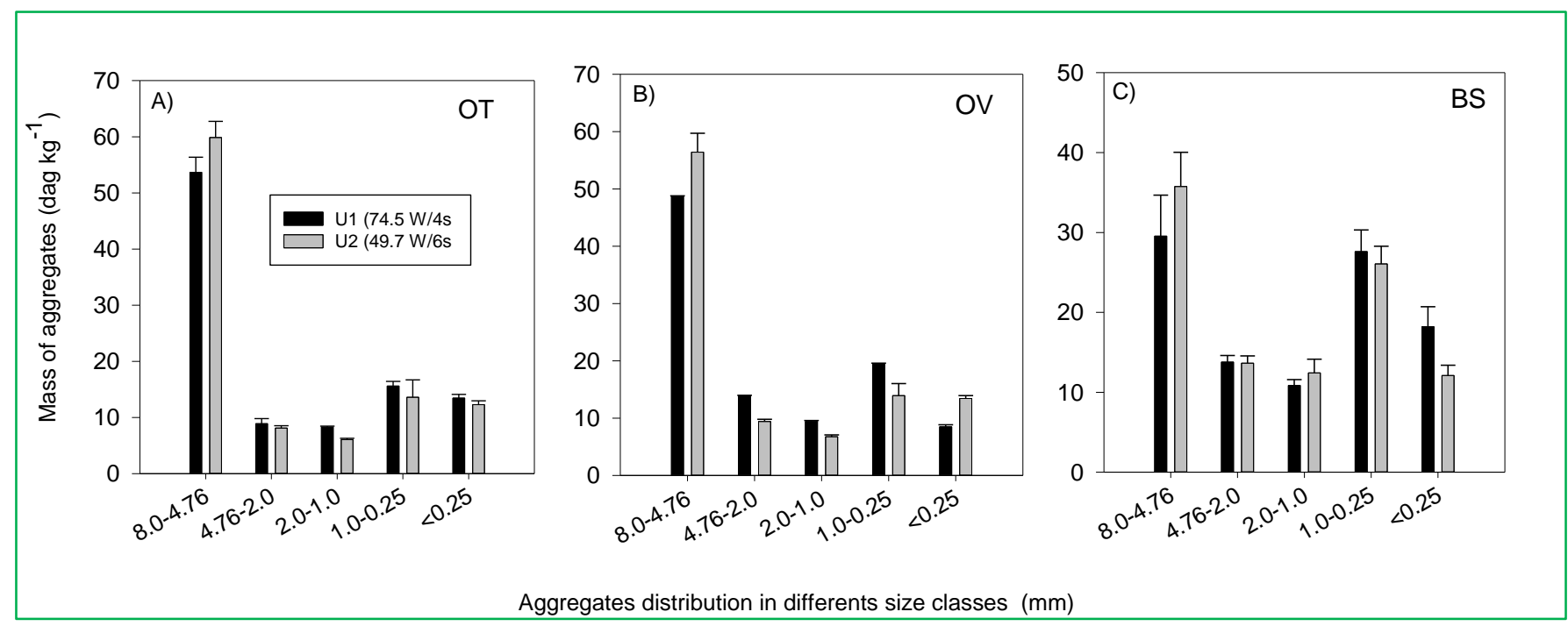

Source: Authors, 2021.

Using U3 (P: $74.5 \mathrm{~W}$ and $\mathrm{T}: 10 \mathrm{~s})$ and $\mathrm{U} 4$ (P: $49.7 \mathrm{~W}$ and $\mathrm{T}: 15 \mathrm{~s})$, which correspond to a total applied energy of $3.725 \mathrm{~J} \mathrm{~mL}^{-1}$ or $29.82 \mathrm{~J} \mathrm{~g}^{-1}$, the same result was observed as with the sonification methods U1 and U2. With the combination of less power and longer time (U4), a greater amount of aggregates was retained in the size class $8.0-4.76 \mathrm{~mm}$ (Figure 5).

Figure 5 - Mass of aggregates (dag $\mathrm{kg}^{-1}$ ) in the different size classes obtained after exposure to the $\mathrm{U} 3$ and U4 sonification methods corresponding to the total applied energy level of $3.72 \mathrm{~J} \mathrm{~mL}^{-1}$ or $29.82 \mathrm{~J} \mathrm{~g}^{-1}$.

OV: oat + vetch, OT: oat + turnip, BS: bare soil.

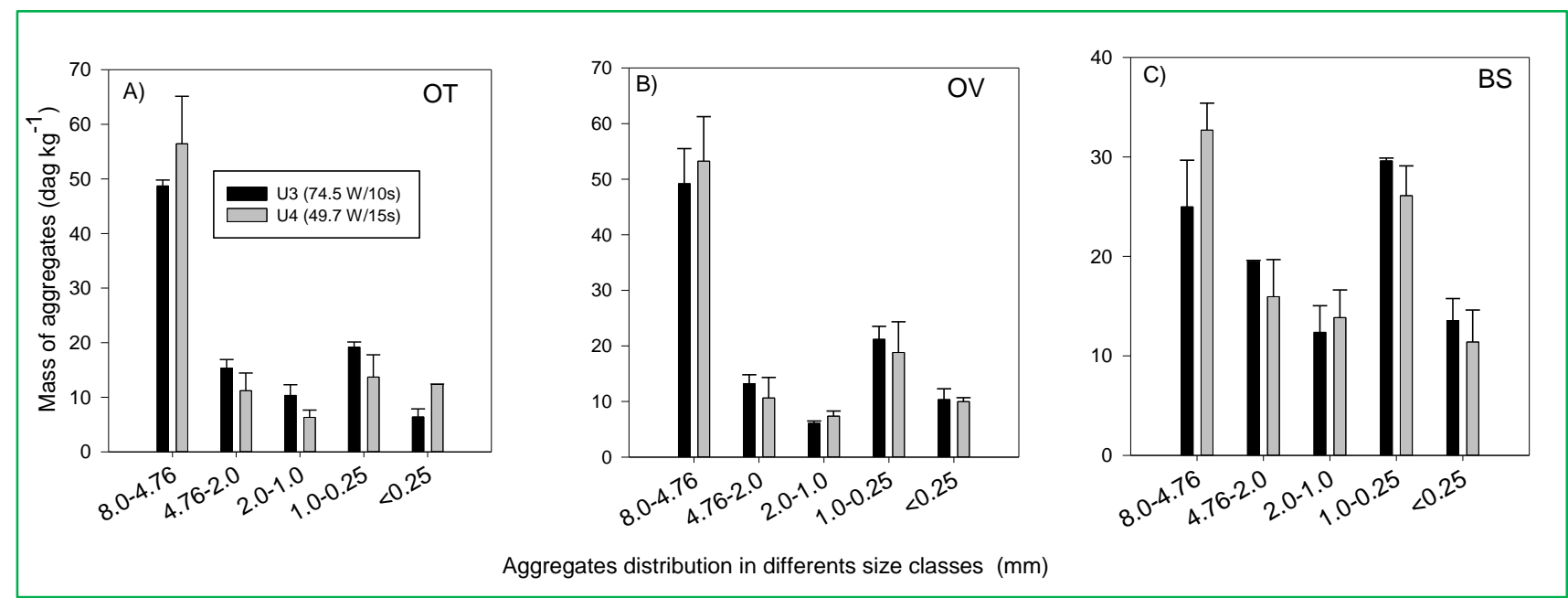

Source: Authors, 2021. 
The cavitation effect (or vibration amplitude) was more pronounced in the absence of vegetal cover (BS). Acoustic pressure waves are emitted into an aqueous suspension, which causes cavitation, stressing of soil aggregates and breaking of aggregate bonds (SCHOMAKERS et al., 2011). At higher vibration amplitudes, higher pressure waves occur and particle disruption is accelerated (MAYER et al., 2002). When the aggregates of BS treatment were exposed to a longer sonification time (6 seconds) but with a lower output power $(49.7 \mathrm{~W})$, there was greater mass of aggregates in larger size classes (8.0-4.76, 4.762.0, $2.0-1.00 \mathrm{~mm}$ ) than in size $<0.25 \mathrm{~mm}$.

Regardless of the combinations of time and power for the determination of the distribution of the aggregates in the different size classes, BS presented greater susceptibility to disaggregation. In this soil management, low amounts of retained aggregates were observed in the largest size class $(8.0-4.76 \mathrm{~mm})$ and, consequently, an increase in the mass of aggregates retained in the lower classes, with emphasis on the concentration of aggregates in the size class of 1.0-0.25 mm (Table 2).

Table 2 - Percentage of aggregates in each size class in the 0.0-0.05 m layer, obtained by ultrassonification, after 18 months of the implantation of the experiment. BS: bare soil, OT: oat + turnip, OV: oat + vetch. Means followed by the same letter in the column did not differ by Tukey test $(p<0.05)$.

\begin{tabular}{|c|c|c|c|c|c|}
\hline & \multicolumn{5}{|c|}{ 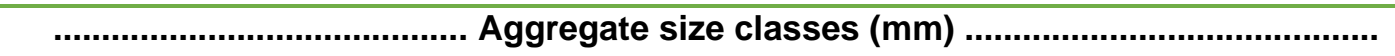 } \\
\hline Treatment & $8.0-4.76$ & $4.76-2.0$ & $2.0-1.0$ & $1.0-0.25$ & $<0.25$ \\
\hline BS & $35.83 \mathrm{~b}$ & $14.53 \mathrm{a}$ & $11.55 \mathrm{a}$ & $25.04 \mathrm{a}$ & $13.04 \mathrm{a}$ \\
\hline OT & 59.19 a & $10.16 \mathrm{~b}$ & $6.37 \mathrm{~b}$ & $15.35 \mathrm{~b}$ & $8.93 \mathrm{~b}$ \\
\hline ov & $60.15 \mathrm{a}$ & $9.90 \mathrm{~b}$ & $6.70 \mathrm{~b}$ & $13.24 \mathrm{~b}$ & $10.00 \mathrm{~b}$ \\
\hline
\end{tabular}

Source: Authors, 2021.

With the WS method the amount of aggregates retained in the class of $8.00-4.76 \mathrm{~mm}$ (Table 3) is greater than with ultrasonic method and, consequently, the aggregation indexes GMD and WMD are higher (Figure 6). With the U1 and U3 ultrasonics methods the amount of aggregates retained in the class of $8.00-4.76 \mathrm{~mm}$ is lower than with WS method and U2 ultrasonic method (Table 3). 
Table 3 - Percentages of aggregates retained in each size class obtained by wet sieving (WS) and ultrasonification $(\mathrm{U})$ in different combinations of time and power. U1: $74.5 \mathrm{~W} / 4 \mathrm{~s}$; U2: $49.7 \mathrm{~W} / 6 \mathrm{~s}$; U3: 74.5 $\mathrm{W} / 10 \mathrm{~s}$ e U4: $49.7 \mathrm{~W} / 15 \mathrm{~s}$. Means followed by the same letter in the column did not differ by Tukey test (5\%).

\begin{tabular}{|c|c|c|c|c|c|}
\hline \multirow[t]{2}{*}{ Method } & \multicolumn{5}{|c|}{ 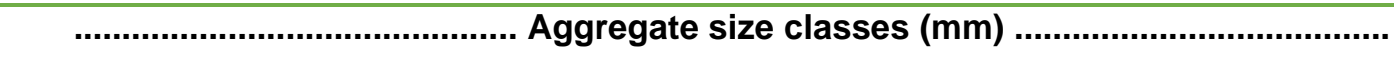 } \\
\hline & $8.0-4.76$ & $4.76-2.0$ & $2.0-1.0$ & $1.0-0.25$ & $<0.25$ \\
\hline WS & $75.55 \mathrm{a}$ & $6.43 \mathrm{~b}$ & $4.31 \mathrm{~b}$ & $7.74 \mathrm{c}$ & $5.97 \mathrm{c}$ \\
\hline U1 & $54.42 \mathrm{c}$ & $12.31 \mathrm{a}$ & $10.20 \mathrm{a}$ & $11.44 \mathrm{~b}$ & $11.63 a b$ \\
\hline U2 & $60.04 \mathrm{~b}$ & $6.16 \mathrm{~b}$ & $6.05 \mathrm{~b}$ & $20.39 \mathrm{a}$ & $7.36 \mathrm{bc}$ \\
\hline U3 & $50.89 d$ & $10.98 a$ & $10.52 a$ & $18.36 a b$ & $9.25 \mathrm{~b}$ \\
\hline U4 & $55.69 \mathrm{c}$ & $12.61 \mathrm{a}$ & $8.18 \mathrm{ab}$ & $11.46 \mathrm{~b}$ & $12.06 \mathrm{a}$ \\
\hline
\end{tabular}

Source: Authors, 2021.

Figure 6- Geometric mean diameter (GMD) (a) and mass-weighted mean diameter (WMD) (b) for the Paleudalf determined by different sonification methods and by the wet sieving method for the three treatments OV, OT and BS. U1: $74.5 \mathrm{~W} / 4 \mathrm{~s}$; U2: $49.7 \mathrm{~W} / 6 \mathrm{~s}$; U3: $74.5 \mathrm{~W} / 10 \mathrm{~s}$ e U4: $49.7 \mathrm{~W} / 15 \mathrm{~s}$; WS: wet sieving. Means followed by the same letter in the column did not differ by Tukey test $(p<0.05)$.

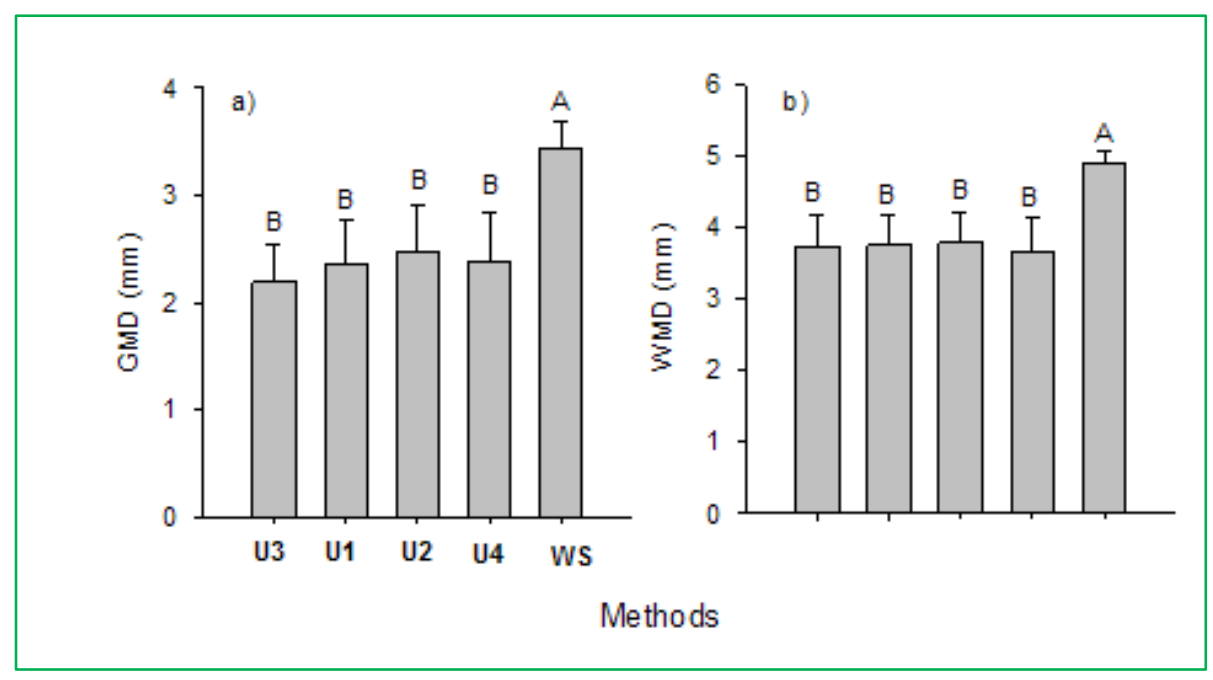

Source: Authors, 2021.

\subsection{STABILITY OF AGGREGATES IN WATER}

In figure 7 are presentation the indexes GMD and WMD calculated for all treatments with the wet sieving method. Lower values of GMD and WMD were observed in the BS treatment. 
Figure 7-Geometric mean diameter (GMD) and mass-weighted mean diameter (WMD) for the Paleudalf under different management systems with cover plants. OV: oat + vetch, OT: oat + turnip, BS: bare soil. Means followed by the same letter not differ by Tukey test $(p<0.05)$.

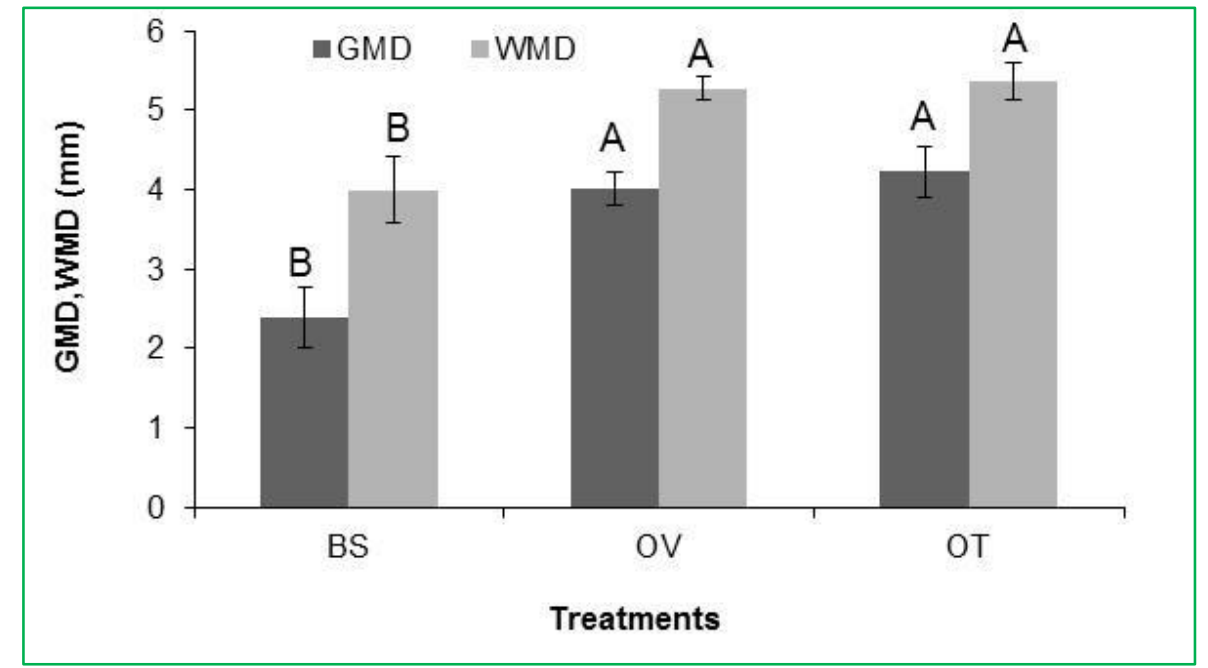

Source: Authors, 2021.

\section{DISCUSSION}

The ultrasonic power applied is significantly affected by the presence of soil, suspension concentration, suspension temperature and depth of probe insertion (RAINE; SO, 1994; RAINE; SO, 1993; SILVA et al., 2016). The depth of immersion of the probe and the volume of the suspension were standardized for all treatments (MAYER et al., 2002; RIBEIRO et al., 2017), therefore, the cavitation intensity (amplitude) decreased due to the increase in the temperature of the suspension (RAINE; SO, 1994; MAYER et al., 2002).

The temperature of the suspension increases with the time of exposure to sonification, which causes a reduction in the propagation efficiency of the energy dissipated by the probe (MAYER et al., 2002). The vibration amplitude is also influenced by the polishing state of the tip, thus, the tips must be replaced when worn (MAYER et al., 2002; SILVA et al., 2016).

In agreement with Raine and So (1997), this study demonstrated that the total energy applied is not enough to explain the effect of sonification on soil disintegration. In other words, the cavitation intensity (vibration amplitude) was more important than the total energy to which a sample of aggregates was exposed (MAYER et al., 2002; SCHOMAKERS et al., 2011). For this reason, the tests conducted at higher intensities (U1 and U3) resulted in greater disaggregating effect for the treatments OT,OV, BS (Figures 3 and 4, Table 3). 
Ribeiro et al. (2017), evaluating the influence of time and power interactions on the disaggregation of an Oxisol macroaggregates managed with coffee plants, observed that even when the same total energy was applied, a high power and a shorter time also had a greater disintegrating effect than when lower power and longer time was applied. These results are justified by the change in cavitation intensity (MAYER et al., 2002; SCHOMAKERS et al., 2011), in other words, the aggregate breakdown was totally dependent on amplitude. In this study, there was greater disaggregation in the amplitude of $40 \mu \mathrm{m}$ (U1 and U3). Mayer et al. (2002) showed that for the same total applied energy the soil dispersion was different by using amplitudes of 23 or $42 \mu \mathrm{m}$ (RIBEIRO et al., 2017).

Regarding the distribution of aggregates in size classes, regardless of the cavitation intensity, a larger mass of stable aggregates $(>2.00 \mathrm{~mm}$ ) was observed in the OV and OT managements (Table 2). The residues from the aerial part and the roots of the cover plants represented continuous addition of soil organic matter capable of stimulating the recycling (maintenance) of aggregates $>0.25 \mathrm{~mm}$ (macroaggregates), which are important for the stabilization of organic carbon over time. Therefore, management systems with cover crops are beneficial to soil aggregation (HOORMAN, 2009).

From the standpoint of sustainable agriculture, management with cover plants (OT and $\mathrm{OV}$ ) contributes to the maintenance of the physical quality of the soil followed by better soil functional performance (HOORMAN, 2009). The pore space responsible for gas exchange and diffusion, root growth, infiltration, and percolation of water is originated by the organization and arrangement of the macroaggregates (ZHANG-LIU et al., 2013).

Regarding the aggregate stability indexes, several studies have shown that GMD and WMD from ultrasonic energy tests are more sensitive to evaluate the effect of management in soil aggregation when compared to wet sieving (SÁ et al., 2000; SILVA et al., 2016; RIBEIRO et al., 2009).

The results of this study demonstrated that by WS the percentage of bigger aggregates is higher and this may be a risk in the evaluation of the stability of aggregates with the different managements. WS method may have overestimated soil aggregation.

In studies on the aggregation effects promoted by management systems used in coffee cultivation in Inceptisol and Oxisol, Silva et al. (2016) observed that GMDs obtained at the ultrasonic energy levels of 6.4 and $12.8 \mathrm{~J} \mathrm{~mL}^{-1}$ were the most sensitive to differentiate the soil depths. However, corroborating with the results found in this study (Table 3), Silva 
et al. (2016) observed that wet sieving overestimated GMD from all evaluated depths (hilled, 0.0-0.20, 0.20-0.40 m).

When using the wet sieving method, Ribeiro et al. (2009) found the same values of GMD for aggregates of the A and Bi horizons of an Inceptisol. However, when GMD was determined by ultrasonic energy, the authors observed that the behavior of the Bi horizon was similar to that of the $\mathrm{C}$ horizon. The $\mathrm{A}$ and $\mathrm{Bi}$ horizons presented similar responses in soil disaggregation by the energy coming from the impact of simulated rain drops and by ultrasonic energy. Thus, the results of this study also demonstrated that the ultrasonic energy represented with more fidelity the soil disintegration process in relation to the wet sieving.

Conservation management systems OT and OV promoted greatest soil structural stability, favoring macroaggregation, with highest values GMD and WMD (Figure 7). It is expected that in the long term, management systems with cover crops can bring improvements to the soil functional performance, especially with the increase of carbon sequestration capacity and benefits for the physical-hydric properties, such as increased water infiltration into the soil (SILVA et al., 2019).

\section{CONCLUSIONS}

The sonification at high power and short periods of time $(\mathrm{U} 1=74.5 \mathrm{~W} / 4 \mathrm{~s}, \mathrm{U} 3=$ $74.5 \mathrm{~W} / 10 \mathrm{~s})$ caused greater disintegrating effect.

Management with cover plants (OT and OV) increased aggregation soil.

\section{REFERENCES}

ALVARES, C. A.; STAPE, J.L.; SENTELHAS, P.C.; DE MORAES, J.L.G.; SPAROVEK, G Köppen's climate classification map for Brazil. Meteorologische Zeitschrift, v.22, n.6, p.711-728, 2013. Doi.org/10.1127/0941- 2948/2013/0507

HOORMAN, J.J. Using cover crops to improve soil and water quality. Lima, Ohio: Agriculture and Natural Resources. The Ohio State University Extension, 2009.

KEMPER, W.D.; CHEPIL, W.S. Size distribution of aggregates. In: BLACK, C.A. (Ed.). Methods of soil analysis. Madison. American Society of Agronomy, v.1, p.499-509, 1965. 
LOSS, A.; BASSO, A.; OLIVEIRA, B.S.; KOUCHER, L.P.; OLIVEIRA, R.A.; KURTZ, C.; LOVATO, P.E.; CURMI, P.; BRUNETTO, G.; COMIN, J.J. Carbono orgânico total e agregação do solo em sistema de plantio direto agroecológico e convencional de cebola.

Revista Brasileira de Ciência do Solo, v.39, p.1212-24, 2015.

Doi.org/10.1590/01000683rbcs20140718

MAYER, H.; MENTLER, A.; PAPAKYRIACOU, M., RAMPAZZO, N.; MARXER, Y.; BLUM, W.E.H. Influence of vibration amplitude on the ultrasonic dispersion of soils. International Agrophysics, v.16, p.53-60, 2002.

NORTH, P.F. Towards an absolute measurement of soil structural stability using ultrasound. Journal of Soil Science, v.27, p.451-459, 1976. Doi.org/10.1111/j.13652389.1976.tb02014.x

PILLI, S.; BHUNIA, P.; YAN, S.; LEBLANC, RJ.; TYAGI, R.D.; SURAMPALLI, R.Y. Ultrasonic pretreatment of sludge: a review. Ultrasonics Sonochemistry, v.18, p.1-18, 2011.Doi.org/10.1016/j.ultsonch.2010.02.014

RAINE, S.R.; SO, H.B. An energy based parameter for the assessment of aggregate bond energy. Journal of Soil Science, v.44, p.249-59, 1993. Doi.org/10.1111/j.13652389.1993.tb00449.x

RAINE, S.R.; SO, H.B. Ultrasonic dispersion of soil in water: The effect of suspension properties on energy dissipation and soil dispersion. Australian Journal of Soil Research, v.32, p.1157-74, 1994. Doi.org/10.1071/SR9941157

RAINE, S.R.; SO, H.B. An investigation into the relationship between dispersion, power, and mechanical energy using the end-over-end shaking and ultrasonic methods of aggregate stability assessment. Australian Journal of Soil Research, v.35, p.41-53, 1997. Doi.org/10.1071/S96063

R DEVELOPMENT CORE TEAM. R: a language and environment for statistical computing. R Foundation for Statistical Computing, Vienna, Austria. 2018.

RIBEIRO, B.T.; LIMA, J.M.; OLIVEIRA, G.C.; CURI, N.; SILVA, E.A.; SILVA, B.M. Ultrasonic aggregate breakdown of an Oxisol as affected by cavitation intensity. Communications in Soil Science and Plant Analysis, v.48, p.818-824, 2017. Doi.org/10.1080/00103624.2017.1299170

RIBEIRO, B.T.; LIMA, J.M.; CURI, N.; OLIVEIRA, G.C. Aggregate breakdown and dispersion of soil samples amended with sugarcane vinasse. Scientia Agricola, v.70, p.435-41, 2013. Doi.org/10.1590/S0103-90162013000600009

RIBEIRO, B.T.; LIMA, J.M.; MELLO, C.R.; SÁ, M.A.C.; OLIVEIRA, G.C. Relationship between raindrops and ultrasonic energy on the disruption of a Haplic Cambisol. Ciência e Agrotecnologia, v.33, p.814-823, 2009. Doi.org/10.1590/S1413-70542009000300021

SÁ, M.A.C.; LIMA, J.M.; SILVA, M.L.N.; DIAS JÚNIOR, M.S. Índices de desagregação do solo baseado em energia ultra-sônica. Revista Brasileira de Ciência do Solo, v.23, p. 525-531, 1999. Doi.org/10.1590/S0100-06831999000300005 
SÁ, M.A.C.; LIMA, J.M.; SILVA, M.L.N.; DIAS JÚNIOR, M.S. Comparação entre métodos para o estudo da estabilidade de agregados em solos. Pesquisa Agropecuária Brasileira, v.35, p.1825-1834, 2000. Doi.org/10.1590/S0100-204X2000000900015

SCHOMAKERS, J.; MENTLER, A.; STEURER, T.; KLIK, A.; MAYER, H. Characterization of soil aggregate stability using low intensity ultrasonic vibrations. International

Agrophysics, v.25, p.165-72, 2011.

SILVA, É.A.; MALLMANN, M.S.; PEREIRA,M.A.; REINERT,D.J.; REICHERT, J.M. Energia ultrassônica na avaliação da macroagregação de um argissolo sob manejo conservacionista com diferentes plantas de cobertura. Agrarian, Dourados, v. 14, n. 52, p. 223-232, 2021. Doi.org/10.30612/agrarian.v14i52.14311

SILVA,É.A.; REINERT,D.J.; REICHERT,J.M.; MALLMANN, M.S.;PEREIRA,M.A.;PONS,S .S.; FOGGIATO, W.S. Soil conservation management with cover crops: effects on critical energy levels, release and dispersion of aggregates. Bragantia, v.78, p.444-453, 2019.

SILVA, É.A.; OLIVEIRA, G.C.; CARDUCCI, C.E.; LIMA, J.M.; MELO, L.B.B.;

BENEVENUTE, P.A.N. Stability of soil aggregates in Latosols and Cambisols via standard method and sonification. African Journal of Agricultural Research, v.11, p.3894-3903, 2016. Doi.org/10.5897/AJAR2016.11192

TEDESCO, M.J.; GIANELLO, C.; BISSANI, C.A.; BOHNEN, H.; VOLKWEISS, S.J. Analysis of Soil, Plants and Other Materials (in Portuguese). Universidade Federal do Rio Grande do Sul, Porto Alegre, RS, Brazil. 1995.

UNITED STATES DEPARTMENT OF AGRICULTURE [USDA]. Keys to Soil Taxonomy. 11ed. USDA-NRCS, Washington, DC, USA, 2010.

ZHANG-LIU, D.; TU-SHENG, R.; CHUN-SHENG, H.; QING-ZHONG, Z.; BLANCOCANQUI, H. Soil Aggregate Stability and Aggregate-Associated Carbon Under Different Tillage Systems in the North China Plain. Journal of Integrative Agriculture, v.12, p. 2114-2123, 2013. 


\section{RESUMO}

Embora resultem numa mesma energia total aplicada, certas combinações de tempo e potência podem corresponder a diferentes intensidades de cavitação, e consequentemente, distintas respostas em índices de agregação podem ser obtidas com ultrassom. Assim, este trabalho objetivou avaliar os efeitos da intensidade da cavitação na distribuição de agregados de um Argissolo sob sistemas de manejo com plantas de cobertura e comparar métodos de determinação da estabilidade de agregados (ultrassom versus peneiramento úmido - WS). Amostras de agregados dos tratamentos solo descoberto, aveia preta + nabo forrageiro e aveia preta + ervilhaca foram expostas à irradiação ultrassônica em diferentes combinações de potência e tempo: $74,5 \mathrm{~W} / 4 \mathrm{~s} ; 49,7 \mathrm{~W} / 6 \mathrm{~s} ; 74,5 \mathrm{~W} / 10 \mathrm{~s}$ e $49,7 \mathrm{~W} / 15 \mathrm{~s}$. $\mathrm{O}$ diâmetro médio geométrico (GMD) e diâmetro médio ponderado (WMD) foram calculados. A amplitude de vibração exerceu maior influência na desagregação do solo do que a energia total aplicada. Em WS observaram-se maiores GMD e WMD.

Palavras-chave: Amplitude de vibração. Ultrassom. Peneiramento úmido.

\section{RESUMEN}

Aunque dan como resultado la misma energía aplicada, ciertas combinaciones de tiempo y potencia pueden corresponder a diferentes intensidades de cavitación y, consecuentemente, distintas respuestas en índices de agregación pueden ser obtenidas con ultrasonido. Por lo tanto, este trabajo fue realizado con el objetivo de evaluar los efectos de la intensidad de cavitación en la distribución de agregados de un Paleudalf bajo manejo con plantas de cobertura y comparar métodos de determinación de estabilidad de agregados (ultrasonido versus tamizado húmedo - WS). Muestras de agregados de los tratamientos suelo desnudo, avena negra + nabos forrajeros and avena negra + arveja vellosa fueron expuestos a la irradiación ultrasónica en diferentes combinaciones de tiempo y potencia: $74.5 \mathrm{~W} / 4 \mathrm{~s} ; 49.7 \mathrm{~W} / 6 \mathrm{~s} ; 74.5 \mathrm{~W} / 10 \mathrm{~s}$ and $49.7 \mathrm{~W} / 15 \mathrm{~s}$. Se calcularon el diámetro medio geométrico (GMD) y el diámetro medio ponderado en masa (WMD). La amplitud de vibración ejerció una mayor influencia en la desagregación del suelo que la energía total aplicada. Se observó el método WS mayores GMD y WMD.

Palabras-clave: Amplitud de vibración. Ultrasonido. Tamizado húmedo. 


\section{LICENÇA DE USO}

Este é um artigo publicado em acesso aberto (Open Access) sob a licença Creative Commons Atribuição 4.0 Internacional (CC BY 4.0), que permite uso, distribuição e reprodução em qualquer meio, desde que o trabalho original seja corretamente citado. Mais informações em: http://creativecommons.org/licenses/by/4.0

\section{CONFLITO DE INTERESSES}

Os autores declaram que não há conflito de interesses neste trabalho.

\section{CONTRIBUIÇÕES AUTORAIS}

Autor 1: Elaboração do projeto de pesquisa, condução das análises laboratoriais, tabulação de dados, e redação do artigo científico.

Autor 2; 3; 4 e 5: Condução do experimento, amostragem, análises laboratoriais, tabulação de dados e redação do artigo científico.

Autor 6 e 7: Coordenador do projeto de pesquisa e elaboração do artigo científico.

\section{FINANCIAMENTO}

O presente trabalho contou com apoio financeiro da Fapergs, Capes e CNPq, que concedeu bolsas de estudos aos autores.

\section{AGRADECIMENTO}

Authors thank CAPES and Fapergs for project funding, Soils Department in Federal University of Santa Maria for logistical support and infrastructure.

\section{COMO REFERENCIAR}

DA SILVA, Érika Andressa; MALLMANN, Micael Stolben; PEREIRA, Monike Andrade; PONS, Sarah Severo; BERTOL, Felipe Dalla -Zen; REICHERT, José Miguel; REINERT, Dalvan José. Macroaggregation of a paleudalf affected by cavitation intensity and management systems with cover plants. Revista Brasileira de Engenharia de

Biossistemas (Tupã), v. 15, n. 2, p. 283-302, 2021. DOI:

http://dx.doi.org/10.18011/bioeng2021v15n2p283-302.

\section{RESPONSABILIBADE EDITORIAL}

Prof. Dr. Fernando Ferrari Putti ${ }^{1}$, Prof. Dr. Paulo Sérgio Barbosa dos Santos ${ }^{1}$, Prof. Dr. Eduardo Festozo Vicente ${ }^{1}$ e Prof. Dr. Diogo de Lucca Sartori ${ }^{1}$

1 Universidade Estadual Paulista "Júlio de Mesquita Filho", FCE - Faculdade de Ciências e Engenharia, Tupã, SP, Brasil. 